масличный,

его

хозяйственно-полезные

качества

//http://www.rsnso.ru/directions/ensuring_quality/publications/?n=805

2. Суханова С.Ф., Азаубаева Г.С., Лещук Т.Л. Степень влияния внешних факторов на показатели функционирования биологических систем // Вестник Курганской ГСХА. - 2017. - № 2 (22). - С. 65-69.

3. Суханова С.Ф., Азаубаева Г.С., Лещук Т.Л. Определение степени влияния внешних факторов на биологические системы // Методы механики в решении инженерных задач: Материалы I Всероссийской науч.-практич. конференции 12 октября 2017 г. - Курган: Изд-во Курганской ГCXА, 2017. - С. 136 - 144.

4. Суханова С.Ф., Лещук Т.Л. Степень влияния некоторых факторов на показатели функционирования живых систем // Актуальные проблемы экологии и природопользования: сборник статей по материалам Всероссийской (национальной) научно-практической конференции. - Курган: Изд-во Курганской ГСХА, 2018. - С.169 - 175.

5. Суханова С.Ф. Внешние факторы, определяющие функционирование биологических систем //Биотехнологические аспекты управления технологиями пищевых продуктов в условиях международной конкуренции: Сб. статей по материалам Всероссийской (национальной)научнопрактической конференции (19 марта 2019 г) - Курган: Изд-во Курганской ГСХА, 2019. - С.407 412.

6. Суханова С.Ф. Изучение корреляционных связей в биологическом объекте под действием кормового фактора // Научное обеспечение безопасности и качества продукции животноводства: сб. статей по материалам III Всероссийской (национальной) научно-практической конференции (23 мая 2019 г). - Курган: Изд-во Курганской ГСХА, 2019. - С. 274-283.

7. Суханова С.Ф. Использование препаратов Сел-Плекс и Кайод в рационах кобыл // Актуальные проблемы и научное обеспечение развития современного животноводства: сборник статей по материалам Всероссийской (национальной) научно-практической конференции (11 апреля 2019 г.) - Курган: Изд-во Курганской ГСХА, 2019. - С. 106 - 112.

8. Тарасова А.О., Суханова С.Ф. Показатели неспецифического иммунитета молодняка лошадей, потреблявших различные дозировки льняного жмыха //The Scientific Heritage. - 2020. - № 55-3 (55). - C. 14-18.

9. Sukhanova S., Pozdnyakova N., Tarasova A. Impact of Linseed Cake in the Diet of Russian Heavy Draft Horses on Productive and Physiological Indicators // Advances in engineering research (International scientific and practical conference "AgroSMART - Smart solutions for agriculture" (AgroSMART 2018). - Vol.151, 2018. - p.p.679 - 684.

10. Суханова С.Ф., Азаубаева Г.С., Лещук Т.Л., Кощаев А.Г. Биометрические методы в животноводстве. - Краснодар: КубГАУ, 2017. - 162 с.

\title{
Тарасова A.O. \\ Показатели неспецефической резистентности у лошадей, потреблявших льняной жмых
}

ФГБОУ ВО «Курганская ГСХА имени Т.С.Мальщева»

(Россия, Курган)

doi: $10.18411 / \mathrm{sr}-10-04-2021-18$

\section{Аннотация}

Приводятся результаты исследований по изучению влияния различных дозировок льняного жмыха на показатели неспецифической резистентности у молодняка лошадей 9 - 12 месячного возраста по периодам опыта (в начале опыта, в середине и в конце опыта). Установлено, что у молодняка лошадей опытных групп, получавших в составе рациона льняной жмых, отмечалась более устойчивая неспецифическая резистентность, о чем свидетельствовали фагоцитарные реакции этих животных. Это выражается в общем укреплении организма, повышении его защитных возможностей в борьбе с различными возбудителями болезней.

Ключевые слова: льняной жмых, рационы, молодняк лошадей, неспецифическая резистентность 


\section{Abstract}

The results of studies on the effect of different dosages of linseed cake on the indicators of nonspecific resistance in young horses of 9-12 months of age for the periods of the experiment (at the beginning, in the middle, and at the end of the experiment) are presented. It was found that the young horses of the experimental groups that received linseed cake as a part of the diet had a more stable nonspecific resistance, as evidenced by the phagocytic reactions of these animals. It is expressed in the general strengthening of the body, increasing its protective capabilities against various pathogens.

Keywords: linseed cake, diets, young horses, nonspecific resistance

«На сегодняшний день РФ входит в десятку мировых лидеров по численности лошадиного поголовья. При этом одной из основных тенденций современного коневодства РФ является увеличение поголовья лошадей на территориях страны. Разрабатываемые стратегии развития отрасли предполагают рост численности животных с 1,4 млн. в 2018 г. до 1,6 млн. к 2025 г» [1]. Основным условием увеличения продуктивности животных является обеспечение полноценного кормления [2 - 6], в том числе за счет использования различных кормов и кормовых добавок в рационах лошадей $[7,8,9]$. В последние годы во всем мире возрос интерес к использованию льна и продуктов его переработки. В практике кормления сельскохозяйственных животных льняной жмых признается одним из лучших.

Научно-хозяйственный опыт провели в ООО «Логиново» Курганской области на молодняке лошадей русской тяжеловозной породы. Опыт провели на молодняке в возрасте с 9 до 12 месяцев. Контрольная группа молодняка 9 - 12 месячного возраста получала основной рацион, 1 опытная - рацион с добавлением льняного жмыха в дозировке 300 г/гол, а 2 опытной - 500 г/гол в сутки.Полученный в опытах цифровой материал подвергли биометрической обработке [10]. Разницу считали достоверной при $\mathrm{P} \leq 0,05$.

Клеточные факторы неспецифического иммунитета у молодняка лошадей по периодам опыта отражены в таблице 1.

Таблийа 1

Показатели неспецифической резистентности у молодняка лошадей по периодам

\begin{tabular}{|c|c|c|c|}
\hline \multirow{2}{*}{ Показатель } & \multicolumn{3}{|c|}{ Группа } \\
\hline & контрольная & 1 опытная & 2 опытная \\
\hline \multicolumn{4}{|c|}{ Начало опыта } \\
\hline Лейкоциты, х $10^{9}$ /л & $9,47 \pm 0,32$ & $9,70 \pm 0,22$ & $9,50 \pm 0,48$ \\
\hline Фагоцитарная активность, \% & $59,00 \pm 0,58$ & $58,67 \pm 1,45$ & $58,33 \pm 1,76$ \\
\hline Фагоцитарное число & $3,61 \pm 0,08$ & $3,56 \pm 0,11$ & $3,55 \pm 0,13$ \\
\hline Фагоцитарный индекс & $6,12 \pm 0,18$ & $6,07 \pm 0,29$ & $6,08 \pm 0,10$ \\
\hline $\begin{array}{l}\text { Фагоцитарная емкость, } \\
\text { тыс. мик. тел }\end{array}$ & $58,06 \pm 3,76$ & $59,05 \pm 4,27$ & $57,85 \pm 3,67$ \\
\hline \multicolumn{4}{|c|}{ Середина опыта } \\
\hline Лейкоциты, х 109 /л & $9,34 \pm 0,17$ & $9,53 \pm 0,08$ & $9,42 \pm 0,11$ \\
\hline Фагоцитарная активность, \% & $58,33 \pm 1,76$ & $60,67 \pm 1,76$ & $61,33 \pm 2,03$ \\
\hline Фагоцитарное число & $3,50 \pm 0,08$ & $3,76 \pm 0,04$ & $3,85 \pm 0,07$ \\
\hline Фагоцитарный индекс & $6,01 \pm 0,25$ & $6,22 \pm 0,23$ & $6,29 \pm 0,32$ \\
\hline $\begin{array}{l}\text { Фагоцитарная емкость, } \\
\text { тыс. мик. тел }\end{array}$ & $56,11 \pm 1,51$ & $59,25 \pm 2,52$ & $59,30 \pm 3,52$ \\
\hline \multicolumn{4}{|c|}{ Конец опыта } \\
\hline Лейкоциты, х $10^{9} /$ л & $9,55 \pm 0,11$ & $9,65 \pm 0,09$ & $9,67 \pm 0,08$ \\
\hline Фагоцитарная активность, \% & $57,00 \pm 1,73$ & $61,33 \pm 0,67$ & $63,33 \pm 1,45$ \\
\hline Фагоцитарное число & $3,48 \pm 0,12$ & $3,83 \pm 0,04$ & $4,01 \pm 0,09$ \\
\hline Фагоцитарный индекс & $6,11 \pm 0,31$ & $6,24 \pm 0,04$ & $6,34 \pm 0,10$ \\
\hline
\end{tabular}




\begin{tabular}{|l|c|c|c|}
\hline $\begin{array}{l}\text { Фагоцитарная емкость, } \\
\text { тыс. мик. тел }\end{array}$ & $58,42 \pm 3,44$ & $60,26 \pm 0,44$ & $61,28 \pm 0,49$ \\
\hline
\end{tabular}

В начале опыта уровень естественной резистентности в группах практически не отличался, но в дальнейшем изменился. К середине опыта у лошадей всех групп отмечалось уменьшение числа лейкоцитов: в контроле на $1,37 \%$, в 1 опытной - на $1,75 \%$ и во 2 опытной - на 0,84\%. Однако, если в контроле одновременно с уменьшением лейкоцитов снижался и уровень клеточного иммунитета, то в опытных эта тенденция не наблюдалась. У лошадей контрольной группы к середине опыта уменьшились: фагоцитарная активность на 0,67\%, фагоцитарное число - на 3,05\%, фагоцитарный индекс - на 1,80\% и фагоцитарная емкость - на 3,36\%. В опытных группах данные показатели, наоборот увеличивались: в 1 опытной на 2,00; 5,62; 2,47 и $0,34 \%$, во 2 опытной - на 3,$00 ; 8,45 ; 3,45$ и 2,51\% соответственно. В середине опыта количество лейкоцитов в контрольной группе было меньше по сравнению с 1 опытной на $2,03 \%$ и на $0,86 \%$, чем во 2 опытной. Фагоцитарная активность в опытных группах была больше, чем в контроле на 2,34 и 3,00\%; фагоцитарное число - на 7,43 и 10,00\%, фагоцитарный индекс - на 3,49 и 4,66\%, фагоцитарная емкость - на 5,60 и 5,69\% соответственно.

В конце исследований количество лейкоцитов увеличилось у лошадей всех групп: в контрольной на 2,25\%, в 1 опытной - на $1,26 \%$ и во 2 опытной - на $2,65 \%$. В конце опыта данный показатель был в контроле меньше на 1,05 и 1,26\% по сравнению с опытными соответственно. У лошадей контрольной группы в конце опыта уменьшилась фагоцитарная активность и фагоцитарное число на 1,33 и 0,57\%, при увеличении фагоцитарного индекса - на 1,66\% и фагоцитарной емкости - на 4,12\%. В 1 и 2 опытных группах все показатели естественной резистентности увеличивались: фагоцитарная активность - на 0,66 и 2,00\%, фагоцитарное число - на 1,86 и 4,16\%, фагоцитарный индекс - на 0,32 и 0,79\%, фагоцитарная емкость - на 1,70 и 3,34\% соответственно. В конце опыта все показатели естественной резистентности были больше в опытных группах: фагоцитарная активность - на 4,33 и 6,33\%, фагоцитарное число - на 10,06 и 15,23\%, фагоцитарный индекс - на 2,13 и 3,76\%, фагоцитарная емкость - на 3,15 и 4,90\% соответственно.

Таким образом, у молодняка лошадей опытных групп, получавших в составе рациона льняной жмых, отмечалась более устойчивая неспецифическая резистентность, о чем свидетельствовали фагоцитарные реакции этих животных. Это выражается в общем укреплении организма, повышении его защитных возможностей в борьбе с различными возбудителями болезней.

$$
* * *
$$

1. Зайцева А.А., Муромцев А.Б. Коневодство - Москва: Издательство Юрайт, 2020. - 196 с

2. Суханова С.Ф., Азаубаева Г.С., Лещук Т.Л. Степень влияния внешних факторов на показатели функционирования биологических систем // Вестник Курганской ГСХА. - 2017. - № 2 (22). - С. 65-69.

3. Суханова С.Ф., Азаубаева Г.С., Лещук Т.Л. Определение степени влияния внешних факторов на биологические системы // Методы механики в решении инженерных задач: Материалы I Всероссийской науч.-практич. конференции 12 октября 2017 г. - Курган: Изд-во Курганской ГСХА, 2017. - С. 136 - 144.

4. Суханова С.Ф., Лещук Т.Л. Степень влияния некоторых факторов на показатели функционирования живых систем // Актуальные проблемы экологии и природопользования: сборник статей по материалам Всероссийской (национальной) научно-практической конференции. - Курган: Изд-во Курганской ГСХА, 2018. - С.169 - 175.

5. Суханова С.Ф. Внешние факторы, определяющие функционирование биологических систем //Биотехнологические аспекты управления технологиями пищевых продуктов в условиях международной конкуренции: Сб. статей по материалам Всероссийской (национальной)научно- 
практической конференции (19 марта 2019 г) - Курган: Изд-во Курганской ГСХА, 2019. - С.407 412.

6. Суханова С.Ф. Изучение корреляционных связей в биологическом объекте под действием кормового фактора // Научное обеспечение безопасности и качества продукции животноводства: сб. статей по материалам III Всероссийской (национальной) научно-практической конференции (23 мая 2019 г). - Курган: Изд-во Курганской ГСХА, 2019. - С. 274-283.

7. Суханова С.Ф. Использование препаратов Сел-Плекс и Кайод в рационах кобыл // Актуальные проблемы и научное обеспечение развития современного животноводства: сборник статей по материалам Всероссийской (национальной) научно-практической конференции (11 апреля 2019 г.) - Курган: Изд-во Курганской ГСХА, 2019. - С. 106 - 112.

8. Тарасова А.О., Суханова С.Ф. Показатели неспецифического иммунитета молодняка лошадей, потреблявших различные дозировки льняного жмыха //TheScientificHeritage. - 2020. - № 55-3 (55). - C. 14-18.

9. SukhanovaS., PozdnyakovaN., Tarasova A. Impact of Linseed Cake in the Diet of Russian Heavy Draft Horses on Productive and Physiological Indicators // Advances in engineering research (International scientific and practical conference "AgroSMART - Smart solutions for agriculture" (AgroSMART 2018). - Vol.151, 2018. - p.p.679 - 684.

10. Суханова С.Ф., Азаубаева Г.С., Лещук Т.Л., Кощаев А.Г. Биометрические методы в животноводстве. - Краснодар: КубГАУ, 2017. - 162 с.

\section{Юшкова Л.Я., Донченко Н.А., Донченко А.С. \\ Важные ветеринарно-санитарные мероприятия (профилактическая дезинфекция, дезинсекция и дератизация)}

Сибирский федеральный научный изентр агробиотехнологий РАН (ФГБУН

СФНЦА РАН)

(Россия, Новосибирск)

doi: $10.18411 / s r-10-04-2021-19$

\section{Аннотация}

Кратко о важности ветеринарно-санитарных мероприятий. Цена услуги может зависеть от таких условий как: площадь, объем и сложность объекта, графика оказания услуги, кратности, времени обработки, количества и местонахождения объектов. Для примера приведены цены на работы по дезинфекции (уничтожение патогенной микрофлоры, бактерии, вирусы, плесневые грибы), дезинсекции (уничтожение любых насекомых), дератизации (уничтожение крыс, мышей, кротов).

Ключевые слова: дезинфекция. дератизация, дезинсекция, цена, ветслужба.

\section{Abstract}

Briefly on the importance of veterinary and sanitary events. The price of the service may depend on conditions such as the area, volume and complexity of the object, the schedule of the service, multiplicity, processing time, number and location of the objects. For example, prices are given for work on Disinfection (destruction of pathogenic microflora, bacteria, viruses, mold fungi). Disinsections (destruction of any insects). Deratizations (killing of rats, mice, moles).

Keywords: disinfection. deratization, disinsection, price, veterinary service.

1. В системе ветеринарно-санитарных мероприятий, обеспечивающих благополучие животноводческих хозяйств по заразным болезням животных, дезинфекция, дезинвазия, дезинсекция и дератизация занимают одно из важных мест. Основное назначение их - уничтожить или обезвредить в окружающей среде возбудителей заразных болезней животных (птиц).

2. Проведение ветеринарной дезинфекции, дезинвазии, дезинсекции и дератизации предусматривается в плане противоэпизоотических мероприятий по каждому предприятию, имеющему животных, а также в 